\title{
特集「地下水と農業の関わり」の掲載にあたって
}

\author{
中村公人* · 土原健雄 ${ }^{* *}$. 吉岡有美 ${ }^{* * *}$
}

\section{Relationship between groundwater and agriculture}

\author{
Kimihito NAKAMURA*, Takeo TSUCHIHARA** and Yumi YOSHIOKA***
}

地下水の利活用と保全を量と質から考える上 で，農業は非常に重要なファクターである。農業 は灌溉のための水資源の一つとして地下水を利用 する場であるとともに, 農地（主に水田）からの 浸透水が地下水涵養に寄与することから地下水を 供給する場でもある。一方, 地下水涵養の過程で 農地に投入された肥料や農薬に起因する様々な化 学物質が地下水に移動するため, 地下水污染の原 因ともなりうる。

農業と地下水に関連した記事について地下水学 会誌をふり返ってみると, 硝酸態窒素による地下 水污染に関連した報告例が多い。2015年57巻 4 号 と2016年58巻 1 号の特集「九州・沖縄地域に押け る帯水層中での硝酸性窒素の動態」に打いては, 農業（水田, 畑地, 畜産) は地下水に対する窒素 負荷源として扱われている（細野ほか，2015；中 川ほか, 2015 ; 石田ほか, 2015 ; 森ほか, 2016； 中西・野村, 2016)。これ以外にも施肥起源の窒 素動態（松永ほか, 2015; 広城ほか, 1996; 鶴巻, 1992）や農薬污染（田瀬ほか, 1989; 藤縄·飯塚, 1990）に関する研究例がみられる。また, 地下水 の水質形成機構においても農業の影響が言及され ている（たとえば，山中・坂本（2016））。

地下水涵養に着目した研究例は, 安定同位体な
どの水質指標を用いることによって水田からの涵 養の程度を評価する研究例がある（たとえば, 涌井・山中 (2006), 吉岡ほか (2018))。また, 水田を利用した積極的地下水涵養の取り組みと して, 熊本地域の転作水田水張り事業（嶋田, 2013), 福井県大野市の冬期水田湛水事業 (岡田, 2016), 長野県安曇野市の麦後湛水検証事業（山 本，2020）が紹介されている。

一方, 地下水の農業利用に関する報告として は, 農業用地下水利用の実態と農業サイドとして の地下水保全の取り組みについて2010年に論説と してまとめられている(中原ほか，2010）。また， 地下水はとくに渴水時に補助水源として利用され るが, 平成 6 年異常渴水に打ける全国での農業用 地下水利用状況を楠本ほか（1996）が報告してい る。このように地下水の農業利用に関する報告は 多いとはいえない。

2014年に水循環基本法が施行されて以降, 地下 水関係者の協働により持続可能な地下水の保全と 利用を図る地下水マネジメントの重要性が認識 されている (内閣官房水循環政策本部事務局, 2019)。地下水関係者の中には, 農家, 土地改良 区，行政の農林関係課などが含まれるが，農業分 野は地下水の利用者であるとともに供給者でもあ

\footnotetext{
* 京都大学大学院農学研究科

** 国立研究開発法人農業・食品産業技術総合研究機構農村工学研究部門

***島根大学学術研究院
} 
るステークホルダーとして, 量と質の両面から地 下水を保全しつつ, 必要に応じた適切な利用を 行っていかなければならない。

このような背景から, 特集「地下水と農業の関 わり」では, 農業と地下水が共生する視点に立っ た三つの事例を紹介する。今号に掲載する一つ目 は, 地下水マネジメントの要素が凝縮されている 地域である愛媛県道前平野に扮ける農業用水と地 下水の関係の実態と問題点を明らかにしたもので ある。二つ目では, 滋賀県愛知川扇状地の水田地 域に掞ける補助水源としての地下水利用の実態を 紹介し, 三つ目は, 静岡県の茶園地域における地 下水の硝酸態窒素污染を改善するために行われた 減肥の効果に関する報告である。これらは次号以 降の掲載予定である。今後の地下水マネジメント における農業分野の使命, 役割を考える一助にな れば幸いである。

\section{参考文献}

石田 聡 - 吉本周平 - 白旗克志 - 土原健雄（2015）：沖 縄県宮古島砂川ダムに扔ける地下水中の硝酸性窒素 濃度分布と地下水流動に関する一考察. 地下水学会 誌, 57 (4)，515-532.

岡田高大（2016）：水と共に生きる大野市の活動～井戸 枯れから始まった地下水保全の取り組み〜。地下水 学会誌, 58 (2), 217-225.

楠本岳志·富田友幸·東 一樹 (1996):「平成 6 年 (1994

年) 列島渇水」に打ける農業用の地下水利用と障害.

地下水学会誌, 38 (4), 323-330.

沜田 純（2013）：広域地下水流動の実態を踏まえた熊 本地域に扔ける地下水の持続的利用を目指した新た な取り組み一地下水資源量維持のための揚水許可制 の導入 - . 地下水学会誌, 55 (2), 157-164.

田瀬則雄 - 佐伯明義 - 伏脇裕一 (1989)：浅間山北麓に 扔ける殺菌剂 PCNBによる地下水污染. 地下水学会 誌, 31 (1), 31-37.

鶴巻道二 (1992) : 浅層地下水の硝酸態窒素. 地下水学 会誌, 34 (3), 153-162.

内閣官房水循環政策本部事務局（2019）：地下水マ ネジメントの手順書 身近な資源を地域づくりに 活かすために. 98p. https://www.kantei.go.jp/jp/ singi/mizu_junkan/tikasui_management/pdf/tikasui_ tejunsho_honpen.pdf (2020.12.12閲覧)

中川 啓・渡辺貴史 · 天野弘基（2015）：長崎県島原市 を対象とした地下水に対する農業由来の窒素負荷ポ テンシャルマップの妥当性について. 地下水学会誌,

57 (4), 483-493.

中西康博 ·野村渉平 (2016)：窒素質化学肥料の影響 による炭酸塩の溶解促進と $\mathrm{CO}_{2}$ 放出. 地下水学会誌, 58 (1), 87-102.

中原正幸·今泉眞之・長田実也 (2010)：農業農村地 域の地下水開発と保全の取り組み. 地下水学会誌,

52 (1)，9-19.

広城吉成 ·横山拓史 · 神野健二 ·和田信一郎 (1996)：

農地利用形態の変化に伴う地下水中硝酸態窒素濃度

及び溶存酸素量の変動. 地下水学会誌, 38 (1), 1-11. 藤縄克之・飯塚宏栄 (1990) : 潜在的地下水污染源とし

ての農薬. 地下水学会誌, 32（3）, 139-146.

細野高啓・林殷田・アルバレス ケリー・森村 茂・

曾 祥勇・森 康二・田原康博・松永 緑・ホセイ

ン シャハダット・嶋田 純 (2015) : 地下水硝酸污 染研究における最新のトレンドと今後の方向性：熊 本地域の事例を通して. 地下水学会誌, 57 (4)，439465.

松永 緑·嶋田 純·三上久美子・細野高啓・利部 慎 . 岩佐耕次 (2015) : 宮崎県都城盆地に扮ける地下水中 の硝酸イオンの分布特性とその自然浄化に関する考 察. 地下水学会誌, 57 (3), 277-293.

森 康二 - 田原康博 - 多田和広 - 細野高啓 - 嶋田 純 -

松永 緑・登坂博行 (2016) : 流域スケールにおける 反応性窒素移動過程のモデル化と実流域への適用性 検討. 地下水学会誌, 58 (1)，63-38.

山中 勝 - 坂本圭之祐 (2016)：群馬県大間々扇状地 に打ける地下水の水質形成機構. 地下水学会誌,

58 (2), 165-181.

山本 晃 (2020) : 長野県安量野市に扔ける地下水ガバ ナンスに係る合意形成事例. 地下水学会誌, 62 (2), 183-189.

吉岡有美 - 伊藤真帆 - 中村公人 · 瀧本裕士 - 土原健雄

（2018）：酸素・水素安定同位体比からみた手取川扇 状地の河川水一地下水の交流現象と地下水涵養源. 地下水学会誌, 60 (2), 205-221.

涌井久司・山中 勝（2006）：安定同位体組成からみた 那須扇状地扇央部における地下水涵養源とその地域 性. 地下水学会誌, 48 (4), 263-277. 